\title{
Rencana Sarana Pengolahan Limbah B3 Covid-19 di Kota Ambon
}

\author{
The Plans Of Covid-19 B3 Waste Management Facilities in Ambon
}

\author{
Adnan Affan Akbar Botanri ${ }^{1}$, Rinaldy Makatita ${ }^{1}$, Vivi Sopacua ${ }^{1}$
}

Diterima: 29 Desember 2020

Disetujui: 10 Februari 2021

\begin{abstract}
Abstrak: Virus Corona atau Covid-19 telah menyerang seluruh Negara tidak terkecuali Negara Indonesia. Virus ini telah menjadi pandemi karena penyebarannya yang cepat dan menyebabkan tingkat kematian yang tinggi. Kota Ambon sebagai salah satu kota di timur Indonesia juga turut tersebar virus corona. Seiring tingginya kasus positif di Kota Ambon, semakin tinggi juga limbah yang dihasilkan dan masuk ke dalam kategori bahan berbahaya dan beracun (B3). Saat ini pemerintah Provinsi Maluku sedang menyiapkan sarana pengolah limbah B3 tersebut, sehingga penelitian ini bertujuan untuk menganalisis lokasi yang tepat. Metode penelitian yang digunakan ialah deskriptif kualitatif dengan menggunakan metode SIG, yakni menganalisis fungsi kawasan dengan parameter kemiringan lereng, jenis tanah dan curah hujan. Fungsi kawasan dapat digunakan sebagai pertimbangan dalam melakukan perencanaan pembangunan suatu wilayah. Setelah itu menggunakan data bangunan sebagai dasar penentuan lokasi yang ideal dengan membuat jangkauan pelayanan 500 meter sesuai dengan standar jarak sarana pengolahan limbah B3 dari bangunan sekitarnya. Hasil penelitian ini mendapatkan empat lokasi alternatif untuk rencana sarana pengolahan limbah B3 di Kota Ambon. Empat lokasi hasil analisis ini, aman untuk dibangun sarana pengolahan limbah bahan berbahaya dan beracun (B3) karena cukup jauh dari tempat tinggal masyarakat.
\end{abstract}

Kata kunci: Covid-19, Limbah B3, Fungsi Kawasan, Kota Ambon

\begin{abstract}
Corona Virus or Covid-19 has taken over all the world, including Indonesia. This virus outbreak has become a pandemic because of its lightning-fast spread and greater number of death rate. Ambon as one of the cities in Eastern Indonesia is also affected by Corona Virus.The higher the positive cases in Ambon, the higher the hazardous and toxic waste production (B3). Now, the government of Maluku province is preparing B3 waste management facilities, so that this research aims to investigate the appropriate location for this waste management. This research was a qualitative descriptive by applying a SIG method, that was analysing the area function with the parameter of slope, soil type, and rainfall. The area function could be used to consider the development plans of an area. Then, the data of buildings was used as a basic to determine the ideal area with the service range of 500 meter in accordance with the standard distance of B3 waste management facilities from surrounding buildings. The research findings show four alternative areas of B3 waste management facilities in Ambon. These four areas are safe to be built hazardous and toxic waste (B3) management facilities since these are located far away from the settlements.
\end{abstract}

Keywords: Covid-19, B3 Waste, Area Function, Ambon City

${ }^{1}$ Dosen Perencanaan Wilayah dan Kota Universitas Pattimura

Korespondensi: abotanri@gmail.com 


\section{PENDAHULUAN}

Virus Corona atau severe acute respiratory syndrome coronavirus 2 (SARS-CoV-2) merupakan virus yang menyerang sistem pernapasan atau biasa disebut COVID-19 (Corona Virus Disease 2019). Covid-19 adalah penyakit baru yang telah menjadi pandemi. Penyakit ini harus diwaspadai karena penularan yang relatif cepat, memiliki tingkat mortalitas yang tidak dapat diabaikan, dan belum adanya terapi definitive (Susilo, 2020)

Virus tersebut dapat menyebabkan gangguan ringan pada sistem pernapasan, infeksi paru-paru yang berat bahkan dapat menyebabkan kematian. Virus ini pertama kali ditemukan di Negara China tepatnya di kota Wuhan pada bulan Desember 2019. Penyebaran virus ini begitu cepat tersebar ke berbagai Negara di Dunia tidak terkecuali menyerang Negara Indonesia.

Menurut data Gugus Tugas Percepatan Penangan Covid-19 Republik Indonesia, jumlah kasus terkonfirmasi positif di Indonesia hingga tanggal 8 November 2020 tercatat sebanyak 437.716 jiwa, dengan tingkat kematian (case fatility rate) 3,3\% yakni 14.614 jiwa. Hingga saat ini masih terus terjadi peningkatan pasien positif dengan persentasi positif tertinggi yakni di Provinsi DKI Jakarta, Provinsi Jawa Timur, dan Provinsi Jawa Barat, begitu juga dengan Provinsi Maluku, walaupun tidak masuk persentase tertinggi di Indonesia, namun terus mengalami peningkatan kasus positif.

Salah satu permasalahan pada saat pandemi ialah limbah infeksius yang tergolong bahan berbahaya dan beracun (B3). Semakin banyaknya pelayanan kesehatan dan masyarakat yang sakit, maka akan semakin banyak pula limbah yang dihasilkan pelayanan kesehatan baik klinik, puskesmas, dan rumah sakit. Oleh sebab itu diperlukan manajemen pengelolaan limbah (Mayang, 2018) Bahan berbahaya dan beracun yang selanjutnya disingkat B3 adalah zat, energi, dan/atau komponen lain yang karena sifat, konsentrasi, dan/atau jumlahnya, baik secara langsung maupun tidak langsung, dapat mencemarkan dan/atau merusak lingkungan hidup, kesehatan, serta kelangsungan hidup manusia dan makhluk hidup lain (UU No. 32, Tahun 2009) yang termasuk limbah infeksius diantaranya yakni berupa sarung tangan bekas, masker bekas, alat suntik bekas, bekas APD serta limbah sisa lainnya. Penanganan limbah lebih lanjut dalam hal pengumpulan, pengangkutan dan pengolahan limbah menjadi tanggung jawab Dinas yang memiliki tugas mengelola limbah di wilayahnya berdasarkan penetapan Kepala Daerah sesuai Surat Edaran Menteri Lingkungan Hidup dan Kehutanan (Keputusan Menteri Kesehatan, 2020)

Limbah B3 covid-19 terbanyak dari Region II Pulau Jawa yakni Banten, DKI Jakarta, Jawa Barat, Jawa Timur, dan Daerah Istimewa Yogyakarta, yakni sebanyak 478,18 ton, sedangkan untuk Maluku yang masuk Region VI dengan Papua dan Papua Barat, yakni sebanyak 18,73 ton. Terdapat beberapa daerah di Indonesia yang tidak memiliki sarana pengolahan limbah B3 berizin yakni Sumatera Barat, Bengkulu, Kalimantan Utara, Gorontalo, Maluku Utara, Maluku, Papua Barat dan Papua (Kwan, 2020)

Kasus positif covid-19 di Provinsi Maluku, persentase tertinggi yakni dari Kota Ambon sebagai Ibu Kota Provinsi. Dengan data kasus positif yang banyak, sehingga dikeluarkan peraturan terkait PSBB di Kota Ambon yakni Peraturan Walikota Ambon Nomor 36 Tahun 2020 Tentang Pelaksanaan Pembatasan Sosial Berskala Besar Pada Masa Transisi Menuju Masyarakat Sehat, Aman dan Produktif di Kota Ambon.

Menurut data gugus tugas covid-19 Kota Ambon, jumlah kasus terkonfirmasi positif hingga tanggal 8 November 2020 tercatat sebanyak 3.219 jiwa, dengan tingkat kematian yakni 35 jiwa. Meningkatnya kasus covid-19 di Kota Ambon tentu saja membuat peningkatan kebutuhan APD (alat pelindung diri) untuk pasien maupun perawat dan dokter. Pada tanggal 28 Mei 2020 ditemukan limbah medis covid 19 di Negeri Suli, Pulau Ambon (Saburomedia, 2020) Belum diketahui oknum yang membuang limbah tersebut, namun hal ini perlu menjadi masalah yang perlu diselesaikan karena bahaya dari limbah tersebut. 
Saat ini Pemerintah Provinsi Maluku sedang menyiapkan Pembangunan Fasilitas Pengolahan Limbah B3 Fasyankes di Desa Wayame/Hative Besar, Kota Ambon. Lahan yang akan dibangun untuk sarana tersebut berada disekitar pemukiman, padahal menurut Persyaratan Izin Pengolahan Limbah Bahan Berbahaya dan Beracun (B3) Dengan Insinerator, jarak atau radius dari bangunan minimal 500 meter (Kementerian Lingkungan Hidup dan Kehutanan, 2020). Sedangkan menurut keputusan kepala badan pengendalian dampak lingkungan, persyaratan lokasi pengolahan limbah B3 di luar lokasi penghasil, yakni pada jarak paling dekat 300 meter dari daerah pemukiman, perdagangan, rumah sakit, pelayanan kesehatan atau kegiatan sosial, hotel, restoran, fasilitas keagamaan dan pendidikan (Keputusan Kepala Badan Pengendalian Dampak Lingkungan, 1995). Berdasarkan hal tersebut peneliti mencoba menganalisis lokasi yang tepat untuk sarana pengolahan limbah B3 covid-19 di Kota Ambon.

\section{METODE}

Metodologi penelitian yang digunakan yakni deskriptif kualitatif. Penelitian ini dilakukan di Kota Ambon. Data yang diperlukan adalah data primer yang didapatkan dengan wawancara dengan Kepala Seksi Pengelolaan Sampah dan Limbah B3, Dinas Lingkungan Hidup Provinsi Maluku, dan data sekunder yang didapatkan dari informasi yang dibuat pihak lain seperti buku, artikel, peta, dll. Penulis menggunakan beberapa parameter sesuai dengan SK Menteri Pertanian No. 837/KPTS/UM/11.1980. Parameter tersebut adalah kemiringan lereng, jenis tanah, dan curah hujan. Berikut adalah tabel parameter tersebut:

Tabel 1. Parameter Kelerengan

\begin{tabular}{cccc}
\hline Kelas & Kemiringan (\%) & Klasifikasi & Nilai Skor \\
\hline 1 & $0-8$ & Datar & 20 \\
2 & $8-15$ & Landai & 40 \\
3 & $15-25$ & Agak Curam & 60 \\
4 & $25-45$ & Curam & 80 \\
5 & $\geq 45$ & Sangat Curam & 100 \\
\hline \multicolumn{4}{r}{ Sumber: SK Menteri Pertanian No. $837 /$ KPTS/UM/11.1980 }
\end{tabular}

Tabel 2. Parameter Jenis Tanah

\begin{tabular}{clcc}
\hline Kelas & \multicolumn{1}{c}{ Jenis Tanah } & Klasifikasi & Nilai Skor \\
\hline 1 & Aluvial, Glei, Planossol, Hidromorf Kelabu, Literite Air Tanah & Tidak Peka & 15 \\
2 & Latosol & Agak Peka & 30 \\
3 & Brown Forest Soil, Non Calcic & Kurang Peka & 45 \\
4 & Andosol, Lateritic Gromusol, Podsolik & Peka & 60 \\
5 & Regosol, Litosol Organosol, Renzine & Sangat Peka & 75 \\
\hline
\end{tabular}
Sumber: SK Menteri Pertanian No. 837/KPTS/UM/11.1980

Tabel 2. Parameter Jenis Tanah

\begin{tabular}{cccc}
\hline Kelas & Curah Hujan (mm/hari) & Klasifikasi & Nilai Skor \\
\hline 1 & $8-13,6$ & Sangat Rendah & 10 \\
2 & $13,6-20,7$ & Rendah & 20 \\
3 & $20,7-27,7$ & Sedang & 30 \\
4 & $27,7-34,8$ & Tinggi & 40 \\
5 & $\geq 34,8$ & Sangat Tinggi & 50 \\
\hline \multicolumn{4}{l}{ Sumber: SK Menteri Pertanian No. $837 /$ KPTS/UM/11.1980 }
\end{tabular}

Bahan yang dibutuhkan dalam penelitian ini adalah peta terkait Kota Ambon, diantaranya peta administrasi, peta bangunan, peta kemiringan lereng, jenis tanah, dan curah hujan. Alat yang dibutuhkan dalam penelitian ini yakni Laptop dengan software ArcGis 10.7. Teknik analisis yang digunakan yakni Pemetaan Fungsi Kawasan 
menggunakan hasil overlay peta kemiringan lereng, jenis tanah dan curah hujan, yang digunakan adalah metode SIG. Setelah dilakukan skoring terhadap ketiga parameter tersebut, selanjutnya dilakukan overlay sehingga menghasilkan peta fungsi kawasan berupa kawasan lindung dan budidaya. Setelah mendapatkan peta fungsi kawasan, kemudian dilakukan penambahan kawasan lindung untuk sempadan pantai dan sungai. Setelah itu perlu dianalisis dengan peta bangunan untuk penentuan lokasi yang tepat dengan radius minimal 500 meter.

\section{HASIL DAN PEMBAHASAN}

\section{Fungsi Kawasan}

Analisis evaluasi fungsi kawasan bertujuan mengetahui ada tidaknya penyimpangan yang terjadi pada penggunaan lahan, agar lahan yang ada dapat dimanfaatkan secara maksimal dan tetap lestari (Baharudin, 2014). Identifikasi penataan ruang khususnya dibidang penatagunaan kawasan lindung dan kawasan budidaya memegang peranan penting dalam rangka mewujudkan ruang kehidupan yang menjamin tingkat produktifitas yang optimal dengan tetap memperhatikan aspek keberlanjutan agar memberikan kenyamanan bagi masyarakat dengan memperhatikan prinsip-prinsip keberlanjutan lingkungan (environmental sustainability) (Yanti, 2018).

Fungsi kawasan diperoleh dengan melakukan overlay peta kemiringan lereng, jenis tanah dan curah hujan. Untuk kemiringan lereng di Kota Ambon, didominasi oleh lereng curam (kemiringan 25-45\%) dengan persentasi 31\% atau dengan luasan 93,89 $\mathrm{km}^{2}$. Untuk jenis tanah didominasi oleh jenis tanah Kambisol, Litosol, Regosol dengan persentasi $72 \%$ atau dengan luasan $215,11 \mathrm{~km}^{2}$.

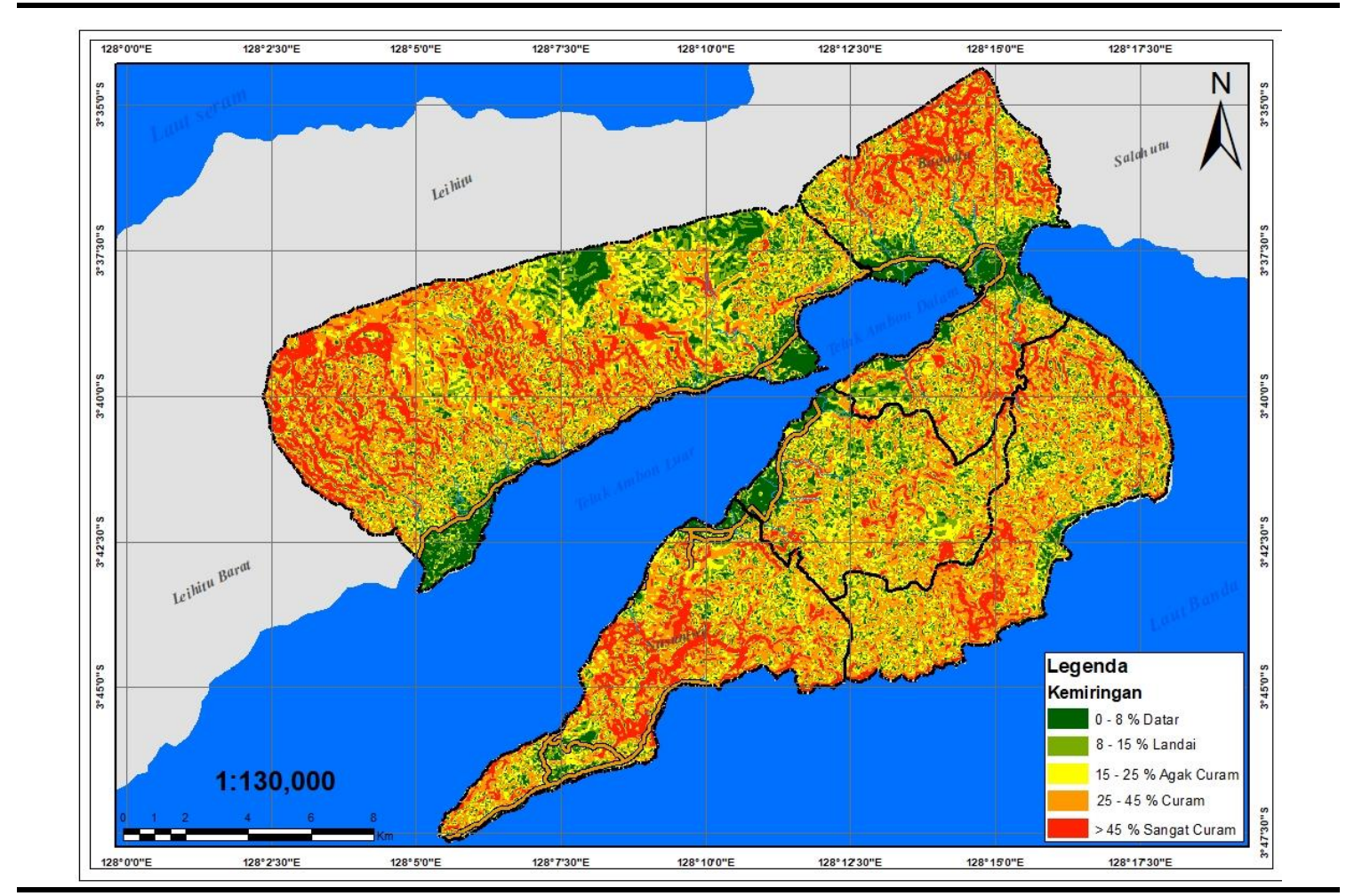

Gambar 1. Peta Kemiringan Lereng Kota Ambon

Untuk curah hujan, Kota Ambon mengalami perbedaan dalam 3 tahun terakhir. Berdasarkan data dari Badan Pusat Statistik Kota Ambon, rata-rata curah hujan di tahun 
2017 yakni 19,4 mm/hari, tahun 2018 mengalami penurunan yakni 15,8 mm/hari dan tahun 2019 kembali mengalami penurunan yakni menjadi 9,5 mm/hari. Data curah hujan tahun 2017 dan 2018 masuk kelas intensitas hujan rendah dengan bobot 20, sedangkan tahun 2019 masuk kelas sangat rendah dengan bobot 10. Data yang akan digunakan peneliti yakni data tahun terakhir sebagai dasar untuk analisis fungsi kawasan.

Setelah dilakukan analisis fungsi kawasan, didapatkan luasan kawasan lindung di Kota Ambon yakni 44,04 $\mathrm{km}^{2}$ dengan persentasi 15\%, sedangkan luasan kawasan budidaya yakni 251,61 $\mathrm{km}^{2}$ dengan persentasi $85 \%$. Fungsi kawasan digunakan sebagai pertimbangan dalam melakukan perencanaan pembangunan suatu wilayah. Dengan mengetahui fungsi kawasan, fokus pembangunan bisa dilakukan pada kawasan budidaya, sedangkan kawasan lindung perlu dijaga kelestariannya. Sesuai dengan Undang-Undang Penataan Ruang, defenisi kawasan lindung yakni wilayah yang ditetapkan dengan fungsi utama melindungi kelestarian lingkungan hidup yang mencakup sumber daya alam dan sumber daya buatan, sedangkan kawasan budidaya yakni wilayah yang ditetapkan dengan fungsi utama untuk dibudidayakan atas dasar kondisi dan potensi sumber daya alam, sumber daya manusia, dan sumber daya buatan (UU No. 26 Tahun 2007).

\section{Data Bangunan}

Data bangunan Kota Ambon digunakan sebagai dasar untuk penentuan lokasi rencana sarana pengolahan limbah B3 covid-19, agar memiliki jarak minimum dari bangunan disekitarnya yakni 500 meter. Penggambaran peta bangunan sesuai dengan data bangunan di Kota Ambon tahun 2020 kemudian dibuat jangkauan pelayanan dengan jarak 500 meter untuk melihat kawasan yang akan dibangun sarana pengolahan limbah tersebut. Saat ini terdapat tiga rumah sakit yang menjadi rujukan pasien covid-19 di Kota Ambon, yakni Rumah Sakit Umum Daerah Dr. M. Haulussy, Rumah Sakit Umum Pusat dr. J. Leimena dan Rumah Sakit Siloam.

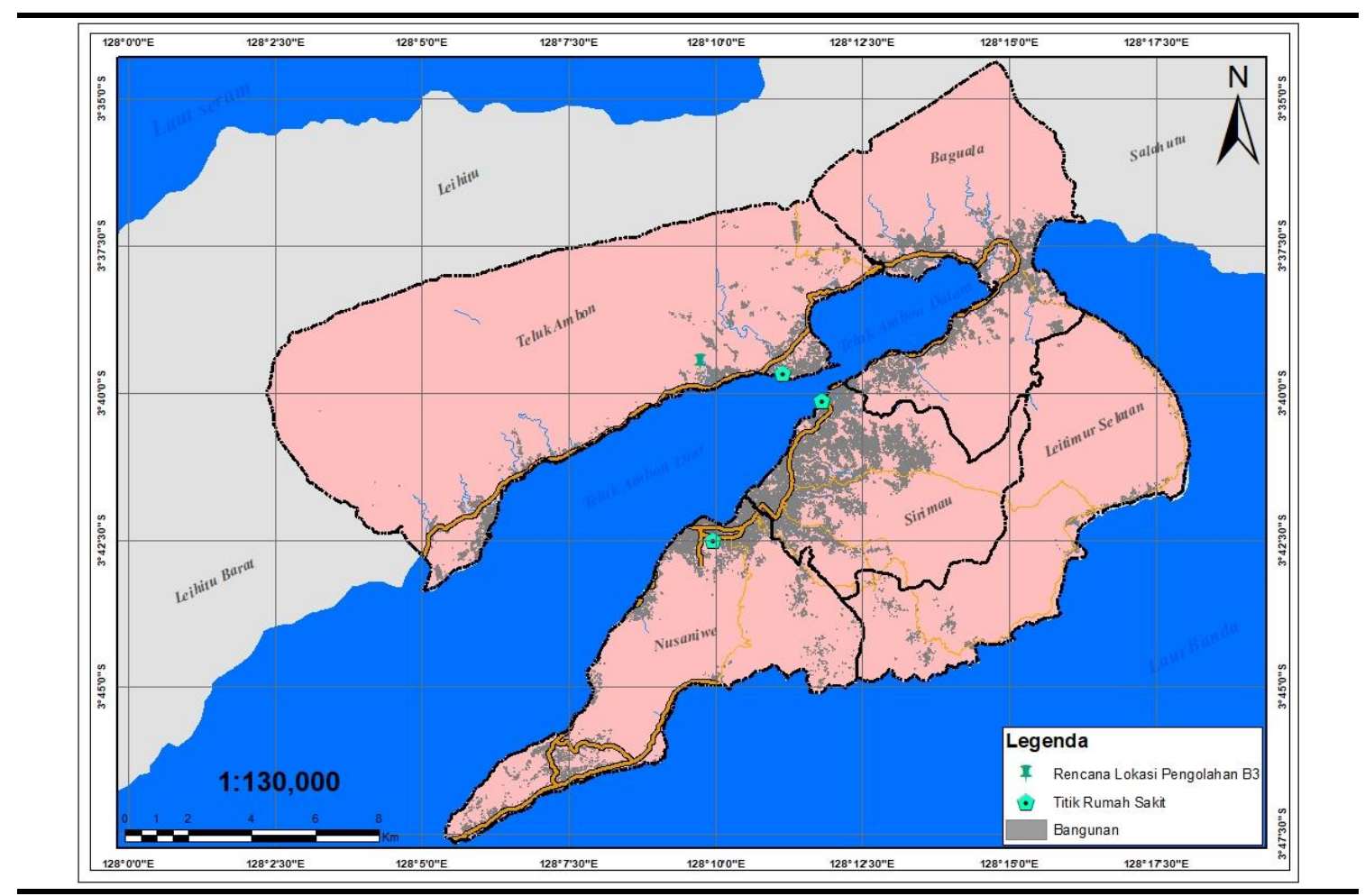

Gambar 2. Peta Bangunan Kota Ambon 


\section{Rencana Sarana Pengolahan Limbah B3 Covid-19}

Rencana sarana pengolahan limbah covid-19 di Kota Ambon didapatkan setelah menganalisis fungsi kawasan dan juga jangkauan pelayanan dari sarana tersebut. Rencana lokasi yang akan dibangun sarana pengolahan limbah di Kota Ambon yakni di Desa Wayame, namun lokasi tersebut berada di dekat permukiman warga. Penulis mencoba menganalisis lokasi yang layak agar tidak memberikan gangguan terhadap lingkungan sekitar.

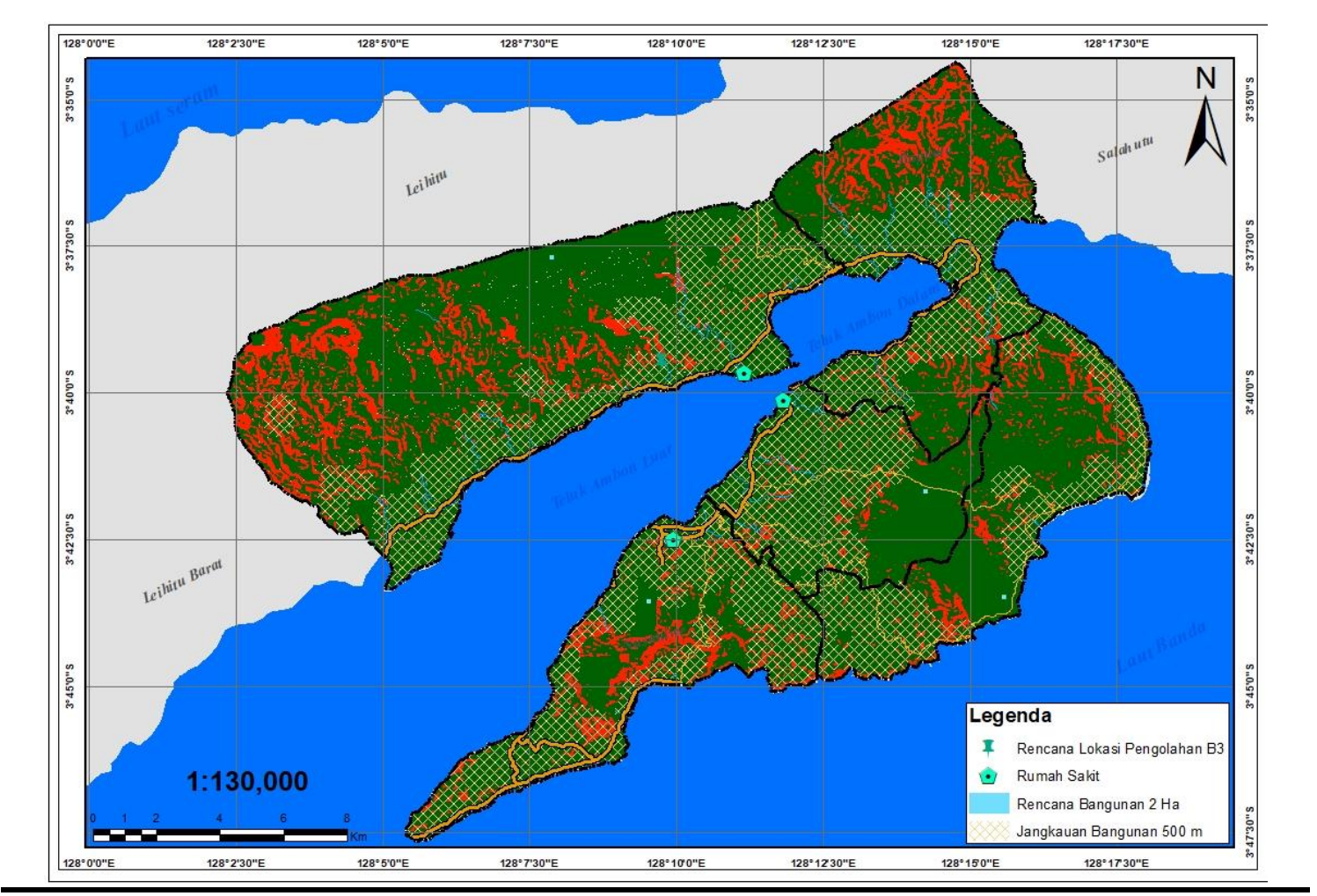

Gambar 3. Peta Rencana Sarana Pengolahan Limbah

Setelah dilakukan analisis berdasarkan jangkauan pelayanan dari bangunan yakni sejauh 500 meter, dipilih empat lokasi yang dapat dijadikan alternatif rencana sarana pengolahan limbah B3 covid-19 di Kota Ambon, yakni di Kecamatan Sirimau, Kecamatan Teluk Ambon, Kecamatan Nusaniwe dan Kecamatan Leitimur Selatan. Hampir disemua kecamatan yang ada di Kota Ambon, terkecuali di Kecamatan Teluk Ambon Baguala karena di kecamatan tersebut mulai banyak pembangunan dan juga wilayah lainnya yang berada diluar radius 500 meter memiliki kemiringan lereng yang curam. Rencana kawasan yang akan dibangun yakni sekitar 2 ha, seperti sarana pengolah limbah B3 covid-19 yang terdapat di Jawa Barat yakni PT. Jasa Medivest Plant dengan luasan sekitar 1,5 ha.

Lokasi pertama yang dapat dibangun yakni di Kecamatan Sirimau tepatnya di Desa Soya. Desa Soya merupakan desa terluas dengan luas wilayah yakni $59,65 \mathrm{~km}^{2}$. Walaupun memiliki luas wilayah terbesar, namun menurut data penggunaan lahan, wilayah tersebut lebih didominasi semak belukar dan hutan, sehingga lebih aman apabila dibangun sarana pengolahan limbah, karena jauh dari permukiman warga. Kondisi eksisting saat ini di desa tersebut, memiliki jalan kolektor sebagai penghubung dari Rumah Sakit Haulussy dan juga Rumah Sakit Siloam namun kondisi jalannya kurang baik. 
Lokasi kedua yakni di Kecamatan Teluk Ambon tepatnya di Desa Hative Besar. Desa Hative Besar juga merupakan desa terluas dengan luas wilayah yakni $30 \mathrm{~km}^{2}$ serta memiliki penggunaan lahan yang didominasi hutan sehingga aman apabila dibangun sarana pengolahan limbah dan juga lokasi dekat dengan Rumah Sakit Leimena. Namun yang menjadi kendala dilokasi tersebut ialah masih terbatasnya jaringan jalan, sehingga apabila dilakukan pembangunan, tentunya perlu terlebih dahulu menyiapkan jaringan jalannya.

Lokasi ketiga yakni di Kecamatan Nusaniwe tepatnya di Desa Amahusu yang memiliki luas wilayah yakni $8 \mathrm{~km}^{2}$. Penggunaan lahan di desa tersebut didominasi hutan dan semak belukar. Di lokasi yang direncanakan belum terdapat akses jalan, namun dapat direncanakan agar terhubung jalan dari Rumah Sakit Haulussy yang berada di Kelurahan Benteng atau bisa juga merencanakan jalan dari wilayah pesisirnya. Rencana di Desa Amahusu merupakan lokasi terdekat dari rumah sakit, dibandingkan tiga lokasi lainnya sehingga dapat menjadi alternatif terbaik dalam pemilihan lokasi.

Lokasi keempat yakni di Kecamatan Leitimur Selatan tepatnya di Desa Hukurila yang memiliki luas wilayah 7,5 $\mathrm{km}^{2}$. Lokasi ini juga didominasi hutan dan semak belukar, selain itu Kecamatan Leitimur Selatan merupakan kecamatan yang paling sedikit kawasan terbangunnya di Kota Ambon selain empat kecamatan lainnya. Pada kecamatan ini juga terdapat Tempat Pembuangan Akhir (TPA) sampah dan juga memiliki akses jalan kolektor yang menghubungkan dengan Kecamatan Sirimau dan juga Kecamatan Teluk Ambon walaupun kondisi jalannya kurang baik dan juga kemiringan lereng yang cukup terjal. Untuk lebih jelasnya dapat dilihat pada tabel 4 terkait perbandingan lokasi beserta dengan kelebihan dan kekurangan masing-masing lokasi.

Tabel 4. Perbandingan Lokasi

\begin{tabular}{cll}
\hline Desa & \multicolumn{1}{c}{ Kelebihan } & \multicolumn{1}{c}{ Kekurangan } \\
\hline Soya & - Penggunaan lahan: semak belukar dan & Kondisi jalan kurang baik \\
& hutan & \\
& - Terdapat jalan kolektor terhubung dengan & \\
Hative Besar & RS Hulussy dan RS Siloam & Tidak memiliki jaringan jalan menuju \\
& - Penggunaan lahan: hutan & lokasi \\
Amahusu & - Lokasi terdekat dengan RS Leimena & Tidak memiliki jaringan jalan menuju \\
& - Penggunaan lahan: semak belukar dan & lokasi \\
& hutan & \\
Hukurila & - Lokasi terdekat dengan RS Haulussy & - Kondisi jalan kurang baik \\
& - Penggunaan lahan: semak belukar dan & - Memiliki kelerengan yang cukup terjal \\
& hutan & \\
& - Merupakan kecamatan dengan kawasan & \\
& terbangun paling sedikit & \\
& - Terdapat TPA & \\
& - Terdapat jalan kolektor terhubung dengan & \\
& Kecamatan Sirimau dan Kecamatan Teluk & \\
& Ambon & \\
\hline
\end{tabular}

Rencana pembangunan sarana pengolahan limbah covid-19 di Kota Ambon dapat mempertimbangkan empat lokasi yang peneliti coba tentukan berdasarkan pertimbangan fungsi kawasan serta jarak dari bangunan sekitar yakni 500 meter. Empat lokasi hasil analisis ini, lebih aman untuk dibangun sarana pengolahan limbah bahan berbahaya, dan beracun (B3) dibandingkan dengan rencana di Desa Wayame karena memiliki jarak yang cukup jauh dari tempat tinggal masyarakat.

\section{KESIMPULAN}

Berdasarkan pembahasan diatas, penulis menarik beberapa kesimpulan, yakni yang pertama, pentingnya melakukan analisis fungsi kawasan sebagai dasar dalam perencanaan pembangunan suatu wilayah, karena itu, penting memiliki data fisik dasar yang valid 
berupa kemiringan lereng, jenis tanah dan curah hujan, terutama Kota Ambon yang memiliki dominasi kemiringan lereng $15-25 \%$ (curam) dan curah hujan yang berbeda dalam dua tahun terakhir. Yang kedua, penentuan lokasi rencana sarana pengolahan limbah bahan berbahaya dan beracun perlu mempertimbangkan jarak 500 meter dari bangunan sekitar, agar tidak membahayakan lingkungan sekitar. Yang ketiga, lokasi yang ditetapkan pemerintah daerah untuk lokasi sarana pengolahan limbah, di Desa Wayame sebaiknya dilakukan alternatif lokasi lain, yakni di Desa Soya Kecamatan Sirimau, Desa Hative Besar Kecamatan Teluk Ambon, Desa Amahusu Kecamatan Nusaniwe dan Desa Hukurila Kecamatan Leitimur Selatan.

Saran dari tulisan ini ialah penulis berharap pertimbangan lokasi rencana sarana pengolahan limbah B3 yang penulis kaji dapat dipertimbangkan sebagai alternatif lokasi selain di Desa Wayame, karena berada pada radius lebih dari 500 meter dari permukiman dan masuk ke dalam kawasan budidaya. Yang berikutnya penulis berharap, pemerintah mempertimbangkan analisis fungsi kawasan sebagai dasar dalam perencanaan pembangunan di Kota Ambon agar terhindar dari permasalahan bencana alam seperti gempa, longsor, banjir dan potensi permasalahan lainnya.

\section{DAFTAR PUSTAKA}

Baharudin, N. A. 2014. Analisis Evaluasi Fungsi Kawasan Dengan Kondisi Lahan Existing Dan Rencana Tata Ruang Wilayah Di Kabupaten Sleman, Yogyakarta. Jurnal

Gugus Tugas Percepatan Penangan Covid-19 Republik Indonesia. 2020. Tersedia pada: https://covid19.go.id/

Gugus Tugas Percepatan Penanganan Covid-19 Kota Ambon. 2020. Tersedia pada: https://ambon.go.id/covid-19/

Kementerian Lingkungan Hidup dan Kehutanan, Pelayanan Terpadu Satu Pintu (PTSP). Manual Persyaratan Izin Pengolahan Limbah B3 Dengan Insinerator. 2020

Keputusan Kepala Badan Pengendalian Dampak Lingkungan Nomor : KEP-03/BAPEDAL/09/1995 Tentang Persyaratan Teknis Pengolahan Limbah Bahan Berbahaya Dan Beracun

Keputusan Menteri Kesehatan Nomor HK.01.07/MENKES/537/2020 Tentang Pedoman Pengelolaan Limbah Medis Fasilitas Pelayanan Kesehatan dan Limbah Dari Kegiatan Isolasi Atau Karantina Mandiri Di Masyarakat Dalam Penanganan Coronavirus Disease 2019 (Covid-19)

Kwan, M. 2020, 23 September. Meninjau Aturan dan Pengelolaan Limbah Infeksius dan Sampah Rumah Tangga Era Covid-19. Tersedia pada: https://www.mongabay.co.id/2020/09/23/meninjau-aturandan-pengelolaan-limbah-infeksius-dan-sampah-rumah-tangga-era-covid-19/

Peraturan Walikota Ambon Nomor 36 Tahun 2020 Tentang Pelaksanaan Pembatasan Sosial Berskala Besar Pada Masa Transisi Menuju Masyarakat Sehat, Aman dan Produktif di Kota Ambon

Mayang, N,. Saputra, I., Sofia, A. 2018. Analisis Kapasitas Insinerator Dan TPS Di Perusahaan Pengolahan Limbah Medis Padat. Jurnal Ilmu Manajemen \& Bisnis Volume 9 Nomor 1

Saburomedia. 2020, 28 Mei. Ditemukan Limbah Medis Covid-19 di Negeri Suli. Tersedia pada: https://www.saburomedia.com/2020/05/28/ditemukan-limbah-medis-covid-19-di-negeri-suli/

Susilo, A., dkk. 2020. Coronavirus Disease 2019: Tinjauan Literatur Terkini. Jurnal Penyakit Dalam Indonesia Volume 7 Nomor 1

Undang-Undang Nomor 32 Tahun 2009 Tentang Perlindungan dan Pengelolaan Lingkungan Hidup

Undang-Undang Nomor 26 Tahun 2007 Tentang Penataan Ruang

Yanti, D. 2018. Identifikasi Kawasan Lindung Dan Kawasan Budidaya Di Desa Kasang Kecamatan Kuantan Mudik. Jurnal Perencanaan, Sains, Teknologi, dan Komputer Volume 1 Nomor 1 